Pak. j. sci. ind. res. Ser. B: biol. sci. 201558 (1) 47-53

\title{
Assessment of Irrigation Water Quality in District Attock, Pakistan
}

\author{
Muhammad Yunas $^{\mathrm{a} *}$, Sarfraz Ahmad ${ }^{\mathrm{a}}$, Bashir Ahmad ${ }^{\mathrm{a}}$, Obaid ur Rehman ${ }^{\mathrm{b}}$ and Sher Afzal ${ }^{\mathrm{a}}$ \\ ${ }^{a}$ Soil and Water Testing Laboratory, Attock, Pakistan \\ ${ }^{\mathrm{b}}$ Soil and Water Conservation Research Station, Fatehjang, Attock, Pakistan
}

(received March 25, 2014; revised September 1, 2014; accepted November 13, 2014)

\begin{abstract}
Water samples (total 277) were collected during previous three years (2008-09 to 2010-11) from all tehsils of Attock district, Pakistan, used for irrigation purpose. Regarding sources of irrigation, 122 samples were collected from bores (turbine operated), 97 from wells, 19 from nullahs and 39 from dams. The analysis data showed that 120 samples (43\%) were fit, 35 samples (13\%) were marginally fit, while 122 samples (44\%) were unfit. As regards minimum and maximum range, it varied in EC from 0.05 to $8.1 \mathrm{dS} / \mathrm{m}$, calcium plus magnesium from 0.6 to $70 \mathrm{meq} / \mathrm{L}$, sodium from zero to $40.6 \mathrm{meq} / \mathrm{L}$, carbonates from zero to $0.04 \mathrm{meq} / \mathrm{L}$, bicarbonates from 0.5 to $15 \mathrm{meq} / \mathrm{L}$, chlorides from 0.2 to $70 \mathrm{meq} / \mathrm{L}$, sodium adsorption ratio from zero to 49.85 and residual sodium carbonate from zero to $13 \mathrm{meq} / \mathrm{L}$. Recommendations for wise and judicious use of marginally fit to unfit irrigation water were imparted to the farmers for raising different arable, fruit and vegetable crops.
\end{abstract}

Keywords: irrigation water, cations, anions, dissolved salts

\section{Introduction}

Crop growing is dependent on an adequate water supply of usable quality. Water quality assessment through analysis is pre requisite for its better utilisation by crops because it is essential for the maintenance of turbidity, absorption of nutrients and metabolic processes of plants. Direct use of unfit irrigation water not only causes severe salinity/ sodicity problems in soil but also depress plant growth to alarming level depending upon the extent of dissolved salts. Water quality concerns remain neglected because plentiful good quality water supplies were readily available. Now, this situation is changing in many areas thus lower quality and less desirable sources are available. 50-60\% of discharge of existing wells is brakish in nature (Ashfaq et al., 2009) that requires interventions for sustainable land use (Hannan et al., 2010). There must be sound planning to ensure that the quality of water available is put to the best use. Conceptually, water quality refers to certain physical, chemical and biological characteristics of a water supply that will influence its suitability for a specific use, i.e., how well the quality meets the needs of the user. Some other common quality characteristics considered are electrical conductivity (EC), sodium adsorption ratio (SAR) and residual sodium carbonate (RSC) (Waheed et al., 2010). Poor quality water can be responsible for slow

*Author for correspondence; E-mail: soilscientist2002@gmail.com growth, poor aesthetic quality of crop and in some cases can result in the gradual death of plants. The scarcity of good quality surface water is becoming more acute day by day therefore, one has to rely on irrigation through tube wells. Thus irrigation through tube wells has advantage over rainfall of being under control with respect to time and amount of application. Water quality should be tested to ensure that it is acceptible for plant growth and to minimise the risk of discharging pollutants to surface or ground water. According to Rizwan et al. (2003) out of 96 water samples, $71 \%$ were fit, 9\% were marginally fit and 20\% were found unfit for irrigation in Rawalpindi district. Even a personal preference such as taste is a simple evaluation of acceptability (Ayers and Westcot, 1994).

Attock district area, Pakistan has gentle to steep topography with deep water table $(15 \mathrm{~m})$ in north east (Tehsil Hazro) to very deep $(120 \mathrm{~m})$ in south west (Tehsils Jand and Pindigheb). In district Attock major crops grown are wheat, gram, ground nut and high value crops (grapes, citrus) for which quality water irrigation is pre-requsite. Crops cultivation in the entire district depends on rainfall. The rainfall pattern is not uniform almost $60-70 \%$ rainfall occurs in months of mid June to mid September. In some areas precipitation is too low, therefore, additional irrigation is required for the optimum yield of the crop especially wheat. The major source of irrigation in the Attock distrct is underground water in the form of dug well and turbines 
and the quality of underground water is not static in the entire district. Soils of district Attock have poor organic matter and other essential nutrients for plants as these soils are calcareous, high in reaction $(\mathrm{pH})$ and mostly light textured. Moisture distribution in the area is not uniform (Rehman et al., 2011). Almost 60-70\% rainfall occurs in months of mid June to mid September. Thus, there is need to conserve soil moisture for boosting crop production. In the recent past, some small dams have been constructed for irrigation, drinking water and fish farming and this development has influenced ground water locally. Shafiq et al. (2005) has classified Attock district into sub humid (Hazro, Bahtar) and semi arid (Attock, Pindi Gheb) and suggested measures to check soil and water erosion. According to Shafiq and Ikram (1996), the undulating field conditions magnify the problems like soil erosion, moisture wastage, over wetness and drought through uneven water distribution in the soil. To overcome the drought stress in rainfed areas, Zia et al. (1996) suggested moisture conservation techniques by tillage practices and mulch application. Water storage provides additional water for the crops and improves water use efficiency. The runoff may also be collected and stored in reservoirs and used for supplemental irrigation. Response to water harvesting is always site specific. Selection of techniques based on different factors such as topography, soil type, land use, pattern and intensity of rainfall, crops to be grown and climatic conditions. Water harvesting technique if appropriately applied could help the establishment of plants without artificial irrigation. Brackish water can be effectively used for irrigation of crops if proper management practices and amendments are followed (Ashraf et al., 2005). Haq et al. (2007) applied both manures and gypsum for mitigating the ill affects of brackish water and improving soil conditions for increasing wheat yield. Jakhar et al. (1994) reviewed the water quality research in Pakistan and described the effect of poor quality irrigation water on crop yield and soil properties.

This study was aimed to provide guideline about water quality of Attock district. This is necessary to ascertain the quality of irrigation water to gauge its possible effects on soil properties and crops yield.

\section{Materials and Methods}

General description of the study area. Water sources for irrigation (surface and underground) of the Attack district (Table 1) covered an area of 3000 ha including 14 perennial streams and nullahs (haro, soan, sill, naindna, dotal, raisi, ghambir, namal, soka, gandakas,
Table 1. Water sources in district Attock

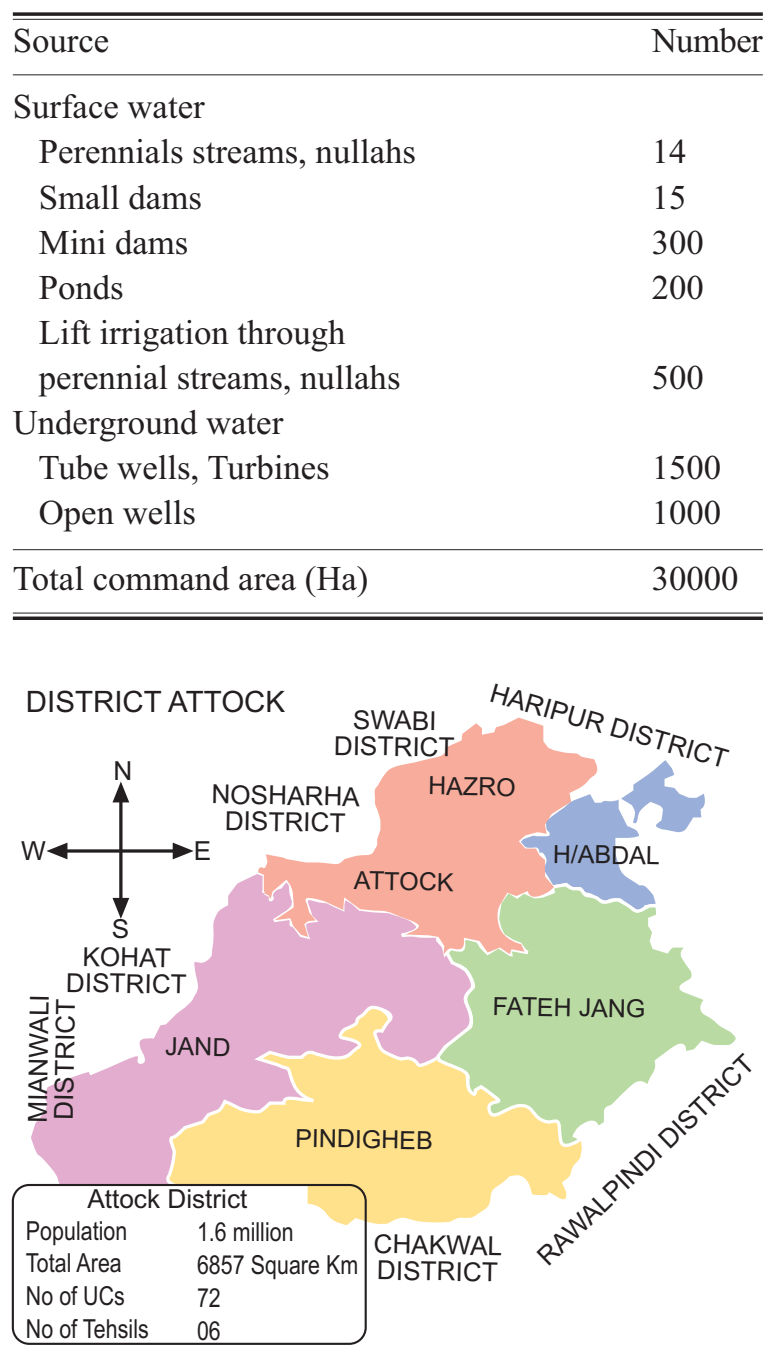

saghar, ghanir, jhablat and kala pani), 15 small dams, 300 mini dams, 200 ponds and 500 lift irrigation schemes from nullahs on the surface water. River Indus and river Soan also running along the boundaries of district Attock from where the nearby farmers use water for irrigation. As regards underground water sources, 1500 turbines are fitted on tube wells besides 1000 open wells operated by bullocks for irrigation. Water sources (surface and underground) and their quality along with impacts on soil and crop production has also been discussed by Chaudhry et al.(1996).

Rainfall is another main source of water for irrigation to crops in Potohar plateau; however, the intensity of rainfall is erratic, especially in Rabi season which defines the cropping pattern. Mean annual rainfall (2008-11) of different tehsils of district Attock is given in Table 2 which shows that maximum rainfall $(755 \mathrm{~mm})$ is received in tehsil 
Table 2. Rainfall (mm) in six tehsils of district Attock (2008-11)

\begin{tabular}{lllllll}
\hline \hline Year & $\begin{array}{l}\text { Hassan } \\
\text { Abdal }\end{array}$ & $\begin{array}{l}\text { Fateh } \\
\text { Jang }\end{array}$ & Attock & Jand & $\begin{array}{l}\text { Pindi } \\
\text { Gheb }\end{array}$ & Mean \\
\hline 2008 & 1171 & 1132 & 702 & 463 & 326 & 759 \\
2009 & 590 & 498 & 479 & 329 & 165 & 412 \\
2010 & 604 & 557 & 511 & 385 & 151 & 442 \\
2011 & 656 & 583 & 533 & 512 & 320 & 521 \\
\hline Mean & 756 & 692 & 556 & 422 & 240 & \\
\hline \hline
\end{tabular}

Hassan Abdal followed by tehsil Fateh Jang (692 mm), Attock (556 mm), Jand (422 mm) and least $(240 \mathrm{~mm})$ in tehsil Pindi Gheb. According to the rainfall ranges classification by Furrukh et al. (1992) i.e., low rainfall (250-500 mm), medium (500-750 mm) and high rainfall zone (>750 mm), Hassan Abdal falls in high rainfall zone, Fateh Jang and Attock lies in medium rainfall zone while Jand and Pindi Gheb are considered in low rainfall zone. This pattern of rainfall may affect the quality of irrigation water used in the district and also the harvesting of runoff water can play key role in crop production. Shafiq et al. (1998) also devised a runoff farming technique for collecting precipitation and storing in the soil profile of the cropped area.

To determine the water quality status for irrigation, samples were collected from all tehsils of district Attock throughout the year in clean plastic/glass bottles of one liter capacity fitted with screw cap. Before taking the sample, each bottle was labeled with water-proof ink showing the name of farmer and address, date of sampling, depth of ground water, crops and soil being irrigated and location. For drawing the maximum benefit and validity, the sample taken was representative of the water in bulk quantity. The well or tube well was run for half an hour prior to sampling and bottle was rinsed several times with the water to be collected and then filled to the top and tightly capped. In case of pond, mini dam or stream, water was filled from inner side of the source. Samples were brought to the laboratory for chemical analysis. The determinations performed were electrical conductivity (EC), cations; calcium + magnesium $(\mathrm{Ca}+\mathrm{Mg})$ and sodium $(\mathrm{Na})$ by difference methods i.e., $\mathrm{TDS}-(\mathrm{Ca}+\mathrm{Mg})$ anions (carbonate $\left(\mathrm{CO}_{3}{ }^{2}\right)$, bicarbonate $\left(\mathrm{HCO}_{3}{ }^{-}\right)$and chloride $\left(\mathrm{Cl}^{-}\right)$, according to the procedures given by Malik et al. (1984). The calculations regarding total dissolved salts (TDS), sodium adsorption ratio (SAR) and residual sodium carbonate (RSC) were worked out as under according to Richards (1954):
Table 3. Fitness criteria of irrigation water

\begin{tabular}{llll}
\hline \hline Parameter & Fit & Marginally fit & Not fit \\
\hline EC $(\mu \mathrm{S} / \mathrm{cm})$ & $0-1000$ & $1000-1250$ & $>1250$ \\
SAR $(\mathrm{mmol} / \mathrm{L})^{0.5}$ & $0-6$ & $6-10$ & $>10$ \\
RSC $(\mathrm{meq} / \mathrm{L})$ & $0-1.25$ & $1.25-2.50$ & $>2.50$ \\
\hline \hline
\end{tabular}

Source: Malik et al. (1984).

$$
\begin{aligned}
& \text { TDS in } \mathrm{g} / \mathrm{m}^{3}=\mathrm{EC}(\mu \mathrm{S} / \mathrm{cm}) \times 0.64 \\
& \text { SAR in } \mathrm{mmol} / \mathrm{L}=\mathrm{Na} /[1 / 2(\mathrm{Ca}+\mathrm{Mg})]^{0.5} \\
& \text { RSC in } \mathrm{meq} / \mathrm{L}=\left(\mathrm{CO}_{3}+\mathrm{HCO}_{3}\right)-(\mathrm{Ca}+\mathrm{Mg})
\end{aligned}
$$

The TDS in $\mathrm{g} / \mathrm{m}^{3}$ (ppm or $\mathrm{mg} / \mathrm{L}$ ) multiplied with the factor 1.23275 gives $\mathrm{kg}$ of salts added per acre foot irrigation. The factor is derived as under:

$\mathrm{EC}(\mu \mathrm{S} / \mathrm{cm}) \times 0.64=\mathrm{mg} / \mathrm{L}$

I acre foot irrigation water $=198 \times 220 \times 1=43560 \mathrm{feet}^{3}$ $\times 28.3 \mathrm{~L}=1232748 \mathrm{~L}$

$1 \mathrm{mg} / \mathrm{L}=10^{6} \mathrm{~kg}$ of salts per liter of irrigation water,

$\mathrm{kg}$ of salts per acre feet of irrigation water $=1232748$ $\times 10^{6}=1.23275$

The criterion of classification (EC, SAR and RSC) for fitness of irrigation water towards its suitability to crops is given in Table 3. Electrical conductivity of soil extract (ECe) is generally 2-3 times higher than electrical conductivity of irrigation water i.e., ECiw (Richards, 1954). Similarly, high SAR and RSC waters will require special considerations before applying to soils and crops.

To ameliorate the ill effects of brackish water on the soil properties and crops, the gypsum requirement of the irrigation water can be calculated by the equation developed by Eaton (1965) which considers two factors, i.e.,

1. Amount of cations and anions present in brackish water 
2. Amount of water to be used for crop production based on the consumptive use of the crops in the rotation

Eaton's equation to calculate the calcium and gypsum requirement of irrigation water.

A. Required $\mathrm{Ca}(\mathrm{meq} / \mathrm{L})=$ Sum of $\mathrm{a}, \mathrm{b} \& \mathrm{c}(\mathrm{a}+\mathrm{b}+\mathrm{c})$ as shown below:

a. $\mathrm{Ca}+\mathrm{Mg}$ needed if any, so that the Na present will not exceed $70 \%$

$=\mathrm{Na} \times 0.43-(\mathrm{Ca}+\mathrm{Mg})$, retain + or- sign

b. Compensate for $\mathrm{Ca}+\mathrm{Mg}$ that will probably be precipitated

$=0.7 \times\left(\mathrm{CO}_{3}+\mathrm{HCO}_{3}\right)$

c. Compensate for $\mathrm{Ca}+\mathrm{Mg}$ in excess of $\mathrm{Na}$ that is removed from the land by average crops $=$ add 0.5 $\mathrm{meq} / \mathrm{L}$

B. Gypsum equivalent of required $\mathrm{Ca}$

$=234 \times(\mathrm{a}+\mathrm{b}+\mathrm{c})$ pounds of gypsum if any, per acre

foot of water

(convert gypsum in tonnes per acre).

\section{Results and Discussion}

Water samples collected for analysis from different sources are presented in Table 4 which shows that $44 \%$ samples were collected from tube wells, $35 \%$ from open wells, $14 \%$ from nullahs and $07 \%$ from the dams. This describes that main source of irrigation water used in the area is tube well which may play role in the soil alkalinity due to rich in $\mathrm{Ca}+\mathrm{Mg}$ and $\mathrm{HCO}_{3}$. The suitability of water for irrigation is actually ascertained considering EC of water, sensitivity of the crops to salinity, soil texture and permeability of the soil to water. On coarse textured soils with high permeability to water, it is possible to use water of higher salinity without adverse effects on crops yields but on soils with high clay percentage and low permeability, water of lower salinity is suitable because addition of irrigated water salts will gather in the soil and yield of salt sensitive crops may be affected.
Table 4. Sources of collected water samples

\begin{tabular}{lll}
\hline \hline Source & Total & Percentage \\
\hline Tube well & 122 & 44 \\
Open well & 97 & 35 \\
Nullah & 19 & 14 \\
Dam & 39 & 07 \\
\hline Total & 277 & 100 \\
\hline \hline
\end{tabular}

Maximum water samples (186 No.) were collected during the year 2008-09 followed by the year 2010-11 (53 No.) and minimum samples (38 No.) were collected in the year (2009-10), as described in Table 5.

The quality of water samples analysed tehsil wise is given in Table 6 while, year wise in Table 7. Quality of water samples shows that $43 \%$ samples were fit, $13 \%$ marginally fit and $44 \%$ samples were not fit for irrigation. It can be inferred from data that quality of available ground water in most of the villages is not suitable for sustainable crop production and soil health.

The results are in accordance with the findings of Ali et al. (2009). In a similar study by Zahid et al. (2003) out of 680 water samples, 33 percent were fit, 19 percent were marginally fit and the rest of 48 percent were unfit. Rizwan et al. (2003) reported the ground water quality for irrigation in Rawalpindi district. Out of 96 water samples, 71 percent were fit, 9 were marginally fit and 20 percent were found unfit for irrigation. Ahmad et al. (1994) analysed 3602 tube well water samples for quality of irrigation and found 15\% samples fit, $31 \%$ marginally fit and $54 \%$ unfit for irrigation. Poor quality water can be used for crop production on a variety of soils when proper agronomic coupled with chemical techniques are followed like the use of gypsum, farm yard manure and salt tolerant crops. Efficiency of irrigation must be increased by the adoption of appropriate management strategies, systems and practices and through education and training (Ali et al., 2009).

For successful crop production on sustainable basis, the quality of groundwater is of main concern. The

Table 5. Water samples collected year wise from tehsils of district Attock

\begin{tabular}{llllllll}
\hline \hline Year & Attock & Jand & Fateh Jang & Pindi Gheb & Hassan Abdal & Hazro & Total \\
\hline $2008-09$ & 95 & 36 & 18 & 16 & 5 & 16 & 186 \\
$2009-10$ & 17 & 3 & 4 & 3 & 1 & 10 & 38 \\
$2010-11$ & 17 & 8 & 15 & 6 & 3 & 4 & 53 \\
\hline Total & 129 & 47 & 37 & 25 & 9 & 30 & 277 \\
\hline \hline
\end{tabular}


Table 6. Quality of water samples (Spatial distribution)

\begin{tabular}{lllll}
\hline \hline Tehsil & Fit & Marginally fit & Unfit & Total \\
\hline Attock & 56 & 18 & 55 & 129 \\
Fateh Jang & 12 & 6 & 19 & 37 \\
Pindi Gheb & 10 & 01 & 14 & 25 \\
Jand & 21 & 05 & 21 & 47 \\
Hassan Abdal & 06 & 01 & 02 & 09 \\
Hazro & 15 & 04 & 11 & 30 \\
\hline Total & 120 & 35 & 22 & 277 \\
\hline \hline
\end{tabular}

Table 7. Quality of water samples (Temporal distribution)

\begin{tabular}{lllll}
\hline \hline Year & Fit & Marginally fit & Not fit & Total \\
\hline $2008-09$ & 71 & 23 & 92 & 186 \\
$2009-10$ & 24 & 3 & 11 & 38 \\
$2010-11$ & 25 & 9 & 19 & 53 \\
\hline Total & 120 & 35 & 122 & 77 \\
\hline \%age & 43 & 13 & 44 & 100 \\
\hline \hline
\end{tabular}

common quality characteristics considered are electrical conductivity (EC), sodium adsorption ratio (SAR) and residual sodium carbonate (RSC) (Idris and Shafiq, 1999). The parameters due to which water sample not fit are given in Table 8 that shows 56\% samples were unfit due to $\mathrm{EC}, 2 \%$ due to $\mathrm{EC}+\mathrm{SAR}$ and samples due to $\mathrm{RSC}, \mathrm{EC}+\mathrm{RSC}, \mathrm{EC}+\mathrm{SAR}+\mathrm{RSC}$ and $\mathrm{SAR}+\mathrm{RSC}$ each were $18 \%, 9 \%, 12 \%$ and $3 \%$, respectively. In general, waters of EC values below $0.75 \mathrm{dS} / \mathrm{m}$ are satisfactory for irrigation and the use of these waters will not create any problem except some salt sensitive crops. However, the use of unfit water due to high EC will cause salinisation (Waheed et al., 2010).

About $70-75 \%$ of the pumped groundwater in the Punjab province is unfit for irrigation owing to high EC, SAR and/or RSC which adversely affects the crop yields (Ghafoor et al., 2001). The ranges of different quality parameters are given in Table 9.

Water samples in arid regions are high in $\mathrm{Ca}+\mathrm{Mg}$ but water samples high in SAR are associated with low $\mathrm{Ca}+\mathrm{Mg}$ relative to $\mathrm{Na}$ concentration. The absence of $\mathrm{CO}_{3}$ and $\mathrm{HCO}_{3}$ is not known to have detrimental effect on plant growth. However, these ions have toxic effects when occur in soil solution in appreciable concentration. Bicarbonates $\left(\mathrm{HCO}_{3}\right)$ associated with $\mathrm{Na}$ causes $\mathrm{Fe}$ chlorosis in plants, reduces elongation in radish seedlings apart from depressing protein synthesis, marked decline in vigour of apples. Carbonate $\left(\mathrm{CO}_{3}\right)$ even in small amounts results in deficiency of $\mathrm{Ca}+\mathrm{Mg}$, renders soil water caustic and corrosion, preventing development of good tilth (Rehman et al., 2011). Higher concentration of $\mathrm{CO}_{3}+\mathrm{HCO}_{3}$ relation to $\mathrm{Ca}+\mathrm{Mg}$ in irrigation water favour accumulation of exchangeable $\mathrm{Na}$. Adding acid or acid forming fertiliser can control the concentration of $\mathrm{CO}_{3}$ and $\mathrm{HCO}_{3}$ in irrigation water. Wilcox et al. (1954) observed adverse effect on soils and plants when RSC exceeds $1.25 \mathrm{meq} / \mathrm{L}$. The water of SAR $<10$ can be safely used on almost all soils. The water of SAR $10-18$ can be safely used on coarse textured soil with

Table 8. Various parameters for water unfitness

\begin{tabular}{|c|c|c|c|c|c|c|c|}
\hline Year & $\mathrm{EC}$ & $\begin{array}{l}\text { EC+ } \\
\text { SAR }\end{array}$ & $\mathrm{RSC}$ & $\begin{array}{l}\mathrm{EC}+ \\
\mathrm{RSC}\end{array}$ & $\begin{array}{l}\mathrm{EC}+\mathrm{SAR} \\
+\mathrm{RSC}\end{array}$ & $\begin{array}{l}\text { SAR+ } \\
\text { RSC }\end{array}$ & Total \\
\hline 2008-09 & 57 & 2 & 15 & 6 & 8 & 4 & 92 \\
\hline 2009-10 & 6 & 0 & 2 & 2 & 1 & 0 & 11 \\
\hline 2010-11 & 5 & 0 & 5 & 3 & 6 & 0 & 19 \\
\hline Total & 68 & 2 & 22 & 11 & 15 & 4 & 122 \\
\hline$\%$ age & 56 & 2 & 18 & 9 & 12 & 3 & 100 \\
\hline
\end{tabular}

Table 9. Different quality parameters range of water samples

\begin{tabular}{lllllllll}
\hline \hline Range & $\begin{array}{l}\mathrm{EC} \\
(\mathrm{dS} / \mathrm{m})\end{array}$ & $\begin{array}{l}\mathrm{Ca}+\mathrm{Mg}^{2+} \\
(\mathrm{meq} / \mathrm{L})\end{array}$ & $\begin{array}{l}\mathrm{Na}^{+} \\
(\mathrm{meq} / \mathrm{L})\end{array}$ & $\begin{array}{l}\mathrm{CO}_{3}^{2-} \\
(\mathrm{meq} / \mathrm{L})\end{array}$ & $\begin{array}{l}\mathrm{HCO}_{3}{ }^{-} \\
(\mathrm{meq} / \mathrm{L})\end{array}$ & $\begin{array}{l}\mathrm{Cl}^{-} \\
(\mathrm{meq} / \mathrm{L})\end{array}$ & $\begin{array}{l}\mathrm{SAR} \\
\mathrm{RSC} \\
(\mathrm{meq} / \mathrm{L})\end{array}$ \\
\hline Minimum & 0.05 & 0.6 & zero & zero & 0.5 & 0.2 & Zero & $\begin{array}{l}\text { Zero } \\
13\end{array}$ \\
Maximum & 8.1 & 70 & 40.6 & 0.04 & 15 & 70 & 49.85 & 13 \\
\hline \hline
\end{tabular}


good soil permeability. The water of SAR 18-26 will cause much greater Na hazard and its use will demand regular application of sufficient water in excess of water requirement to flush out sodium salt deposited by irrigation and it is feasible under conditions of satisfactory drainage. The water of SAR $>26$ is unsatisfactory for irrigation and can be treated with $\mathrm{H}_{2} \mathrm{SO}_{4}$ or $\mathrm{CaSO}_{4}$. There is usually no single way to achieve salinity control in irrigated lands and associated waters. Many different approaches and practices can be combined into satisfactory control systems. The appropriate combination depends upon economic, climatic and social as well as hydro-geologic situations. It can be inferred from the data that quality of available ground water in some of the villages is not suitable for sustainable crop production and soil health. Installation of private tubewells in the area under study must be site specific, keeping in view the ground water quality data. Also farmers of locality may be aware of the existing situation of ground water for irrigation purpose (Shafiq and Saleem, 2013).

\section{Conclusion}

Soil and Water Testing Laboratories at district level in the Punjab provide advisory services and useful guidelines and suggestions/recommendations to the farmers on the basis of analysis. Different quality parameters of irrigation water in district Attock, are described as under:

1. By the data regarding water analysis, 43 percent of the water samples reflecting the good quality water for irrigation in the district which may be the signal for the potential agriculture in the area.

2. Water with high SAR/RSC can be reclaimed by putting gypsum blocks in the water tank or channel. In the soil to be irrigated, 20-40 bags of powdered gypsum per year on the basis of gypsum requirement should be mixed in soil to avoid deleterious effects of water on soil properties and crops.

3. Organic manures like farm yard manure (FYM) and poultry manure (PM) are advised for application for lowering soil $\mathrm{pH}$ to dissolve/activate native calcium.

4. Green manuring with guar, sesbania and alfalfa, etc. should be practiced in monsoon season and rottening be completed before sowing of Rabi crop.

5. Salt tolerant species of crops, fruits and vegetables to EC and SAR are advised on the soils irrigated with saline sodic water.

\section{References}

Ahmad, M.Y., Pervez, K., Iftikhar, A., Mahmood, S. 1994. Quality of tube well waters in district Sheikhupura. Journal of Animal and Plant Science, 4: 119-121.

Ali, M.S., Mahmood, S., Chaudhry, M.N., Sadiq, M. 2009. Irrigation quality of ground water of twenty villages in Lahore district. Soil \& Environment, 28: 17-23.

Ashfaq, M., Griffith, G., Hussain, I. 2009. Economics of Water Resources in Pakistan, 230 pp., Pak TM Printers, Lahore, Pakistan.

Ashraf, M., Rahmatullah, Gill, M.A. 2005. Irrigation of crops with brackish water using organic amendments. Pakistan Journal of Agriculture Sciences, 42: 33-37.

Ayer, R.S., Westcot, D.W. 1994. Water Quality and Agriculture. FAO Irrigation and Drainage Paper No. 29, Rev. 1. Food and Agriculture Organization of the United Nations, Rome, Italy.

Chaudhry, M.R., Zuberi, M.A., Beg, A. 1996. Water resources of Pakistan: Impact on soil and crop production. Pakistan Journal of Soil Sciences, 11: 172-178.

Eaton, F.M. 1965. Water logging and salinity in Indus plain; Comment. Pakistan Development Review, 5: 381-392.

Furrukh, A.M., Saeed, I., Dawson, M., Ahmad, Z. 1992. Farmers and rationale for fertility-moisture management in rainfed Punjab (Pakistan) Journal of Agricultural Research, 30: 371-379.

Ghafoor, A., Gill, M.A., Hassan, A., Murtaza, G., Qadir, M. 2001. Gypsum: An economical amendment for amelioration of saline-sodic waters and soils for improving crop yields. International Journal of Agriculture and Biology, 3: 266-275.

Hannan, A., Ahmed, M., Niaz, A., Ali, L., Waheed, T. 2010. Ground water quality characterization and its correlation with wheat yield. Soil \& Enviornment, 29: 172-176.

Haq, I., Muhammad, B., Iqbal, F. 2007. Effect of gypsum and farm yard manure on soil properties and wheat crop irrigated with brackish water. Soil \& Environment, 26: 164-171.

Idris, M., shafiq, M. 1999. Irrigation quality of groundwater in Quetta division of Baluchistan. Pakistan Journal of Soil Sciences, 16: 119-122.

Jakhar, R.A., Iqbal, J., Hussain, N., Dogar, M.S. 1994. A review of water quality research in Pakistan. Pakistan Journal of Soil Sciences, 9: 10-17.

Malik, D.M., Khan, M.A., Chaudhry, T.A. 1984. Analysis 
Manual for Soils, Plants and Water, 76 pp., Soil Fertility Survey and Soil Testing Institute, Lahore, Pakistan.

Rehman. O., Ahmad, B., Afzal, S. 2011. Sources and quality of irrigation water in district Attock. Journal of Agricultural Research, 49: 203-220.

Richards, L. A. (ed.). 1954. Diagnosis and Improvement of Saline and Alkali Soils, 70 pp., USDA Handbook No. 60, US Salinity Lab. Staff, Washington, DC., USA.

Rizwan, K., Mahmood, T., Abbas, Z., Dilshad, M. Lone, M.I. 2003. Ground water quality for irrigation in Rawalpindi district. Pakistan Journal of Soil Sciences, 22: 43-47.

Shafiq, M., Saleem, M. 2013. Quality Assesment of ground water for irrigation in district Jhang. Journal of Agircultural Research, 51: 149-160.

Shafiq, M.,Rashid, A., Mangrio, A.G. 2005. Agricultural potential of soil resources of the Pothwar plateau. Soil \& Environment, 24: 109-119.

Shafiq, M., Ahmad, B., Ikram, M.Z. 1998. Improvement in water harvesting from catchments by compaction and sodium carbonate under variable slope gradients. Pakistan Journal of Soil Sciences, 14: 27-31.

Shafiq, M., Ikram, M.Z., Ahmed, S., Nasir, A. 1996. Surface runoff and soil loss under cropped fields in medium rainfall zones of Pothwar plateau. Journal of Engineering and Applied Sciences, 15: 71-76.

Waheed, A., Khalid, R., Mahmood, T., Siddique, M.T., Javed, A.S. 2010. Quality of groundwater for irrigation in tehsil Taxila of district Rawalpindi, Punjab. Soil \& Enviornment, 29: 167-171.

Wilcox, L.V., Blair, G.Y., Bower, C.A. 1954. Effect of bicarbonate in water for irrigation. Soil Science, 77: 259-265.

Zahid, P., Kazmi, S.S.H., Gill, K.H. 2003. Characterisation of irrigation water quality of ground water in Gujrat district. Pakistan Journal of Soil Sciences, 22: 48-54.

Zia, M.S., Aslam, M., Nizami, M.M., Ali, A., Saeed, Z. 1996. Rainfed Agriculture: Problems and Management. Pakistan Journal of Soil Sciences, 11: 164-171. 